$12-1-1998$

\title{
Phorbol 12-Myristate 13-Acetate Stimulates Lysophosphatidic Acid Secretion from Ovarian and Cervical Cancer Cells but Not From Breast or Leukemia Cells
}

\author{
Zhongzhou Shen \\ Cleveland State University \\ Jerome Belinson \\ Cleveland Clinic Foundation \\ Richard E. Morton \\ Cleveland Clinic Foundation \\ Yan Xu \\ Cleveland State University, y.xu@csuohio.edu
}

Follow this and additional works at: https://engagedscholarship.csuohio.edu/scichem_facpub

Part of the Biochemistry Commons, and the Chemistry Commons

How does access to this work benefit you? Let us know!

\section{Recommended Citation}

Shen, Zhongzhou; Belinson, Jerome; Morton, Richard E.; and Xu, Yan, "Phorbol 12-Myristate 13-Acetate Stimulates Lysophosphatidic Acid Secretion from Ovarian and Cervical Cancer Cells but Not From Breast or Leukemia Cells" (1998). Chemistry Faculty Publications. 205.

https://engagedscholarship.csuohio.edu/scichem_facpub/205

This Article is brought to you for free and open access by the Chemistry Department at EngagedScholarship@CSU. It has been accepted for inclusion in Chemistry Faculty Publications by an authorized administrator of EngagedScholarship@CSU. For more information, please contact library.es@csuohio.edu. 


\title{
Phorbol 12-Myristate 13-Acetate Stimulates Lysophosphatidic Acid Secretion from Ovarian and Cervical Cancer Cells but Not from Breast or Leukemia Cells
}

\author{
Zhongzhou Shen, Ph.D. Jerome Belinson, M.D. Richard E. Morton, Ph.D. Yan Xu, Ph.D. and Yan Xu, Ph.D
}

\section{INTRODUCTION}

Ovarian cancer ranks second in incidence among gynecological cancers and will cause an estimated 14,500 deaths in 1998 in the United States. More than 70\% of women diagnosed with ovarian cancer have the disease at an advanced stage and the 5-year survival rate for these women remains very poor [1-3]. If the disease is detected at Stage I, the long-term survival rate approaches $90 \%[1-3]$. Therefore, to improve the overall outcome of this disease, significant progress in two areas is required: (i) development of methods of early detection that are highly sensitive and highly specific and (ii) a further understanding of growth regulation in ovarian cancer through the study of growth factors and their mechanism of action, leading toward the identification of potential new targets for therapy.

\footnotetext{
${ }^{3}$ Abbreviations used: LPA, lysophosphatidic acid; PMA, phorbol 12-myristate 13-acetate; $\mathrm{PKC}$, protein kinase $\mathrm{C}$; $\mathrm{CPLA}_{2}$, cytosolic phospholipase $\mathrm{A}_{2}$; iPLA ${ }_{2}, \mathrm{Ca}^{2+}$-independent phospholipase $\mathrm{A}_{2} ; \mathrm{sPLA}_{2}$, secretory phospholipase $\mathrm{A}_{2}$; TLC, thin layer chromatography; OCAF, ovarian cancer activating factor; ER, estrogen response.
}

The growth of ovarian tumor cells is regulated by a number of growth factors/cytokines, including epidermal growth factor (EGF), transforming growth factor $\beta$, amphiregulin, basic fibroblast growth factor, insulin-like growth factor, interleukin 1 , and tumor necrosis factor $\alpha$ [4-7]. Ascitic fluid from ovarian cancer patients stimulates the proliferation of ovarian cancer cells both in vitro and in vivo (nude mice) $[8,9]$. Ascitic fluid also stimulates intracellular calcium release from ovarian cancer cells, an activity not associated with any of the peptide factors mentioned above [8], suggesting it contains a novel factor(s).

We have purified and identified a factor in ascites from ovarian cancer patients and have termed it ovarian cancer activating factor, or OCAF. The most striking feature of this factor is that it is not a peptide factor, but a lipid molecule. OCAF is composed of several molecular species of lysophosphatidic acid (LPA) ${ }^{3}[10,11]$. OCAF or synthetic LPA (oleoyl) induces proliferation of ovarian cancer cells as assessed by $\left[{ }^{3} \mathrm{H}\right]$ thymidine incorporation, MTT dye reduction, and colony formation assays [10-12]. LPA is approximately four times more efficient than EGF in inducing colony formation in SKOV3 cells and 80 times more efficient in OCC1 cells [12]. Importantly, normal ovarian epithelial cells do not respond to LPA $[8,9]$. 
LPA is a normal constituent of serum, but it is not detectable in freshly isolated blood or plasma from healthy individuals [13-17]. Since we have found that LPA is present in ascites from ovarian cancer patients, we investigated whether LPA was also present in the plasma from patients with ovarian cancer and evaluated its potential as a marker for ovarian cancer. We found that ovarian cancer patients had significantly higher plasma LPA levels compared with controls. Higher LPA levels were also detected in the plasma from a majority of patients with other gynecologic carcinomas, but only in a minority of patients with benign gynecological diseases, and it was not detected in patients with breast cancer or leukemias [18].

While we are prospectively evaluating LPA as a potential marker for early detection, we have also begun to study the source and the mechanism underlying the elevated LPA levels in patients with ovarian and other gynecological cancers. The only LPA source that has been studied extensively is activated platelets $[13,14,19,20]$. However, since we have observed that over $95 \%$ of gynecological cancer patients have elevated LPA levels in their plasma, whereas patients with breast cancer and leukemia do not [18], it seems unlikely that a nonspecific platelet effect could explain the unique association of gynecological cancer and elevated plasma LPA. Intriguingly, malignant effusions from ovarian cancer have been reported to contain high LPA-like activity assayed by a semiquantitative neuronal cell shape change assay, compared with effusions from other tumors, including breast and lung cancer [21]. These data suggest that there may be increased production of LPA associated with ovarian cancer. Therefore, we postulate that the malignant cancer epithelial cells might be responsible for the production and secretion of LPA into the blood.

In the present study, we tested whether ovarian, cervical, breast cancer, and leukemia cells could produce and release LPA. The enzymes involved in LPA production were also investigated.

\section{MATERIAL AND METHODS}

Materials. Precoated silica gel 60 TLC plates were obtained from EM Science (Gibbstown, NJ). Lysophosphatidic acids (palmitoyl, oleoyl, and stearoyl LPAs) were purchased from Avanti Polar-lipids, Inc. (Birmingham, AL). Lysophosphatidylcholine, lysophosphatidylinositol, lysophosphatidylserine, lysophosphatidylethanolamine, 8-anilino-1-napthtalenesulfonic acid, ammonium hydroxide, and PMA were obtained from Sigma, Inc. (St. Louis, MO). All other organic solvents were chromatographic grade and from Fisher (Pittsburgh, PA). HEY cells were a gift from G. Mills, M.D. Anderson, Texas [9]. OCC1, Hela, Jurkat, K562, MCF7, and MBMDA-231 were purchased from the American Type Culture Collection (Rockville, MD). Fetal bovine serum (FBS), trypsin-EDTA, glutamine, RPMI 1640, and DMEM/F12 were obtained from Fisher Scientific (Pittsburgh, PA). Gentamycin was obtained from GIBCO-BRL (Grand Island, NY).
Mammalian cell culture. HEY, OCC1, Hela, Jurkat, K562, MCF7, and MB-MDA-231 were cultured in complete RPMI 1640 supplemented with $10 \%$ FBS, $2 \mathrm{mM}$ glutamine, and 50 $\mu \mathrm{g} / \mathrm{ml}$ gentamycin in T75 flasks till cells reached $80-90 \%$ confluence. Cells were starved in $10 \mathrm{ml}$ DMEM/F12 (50/50) with $2 \mathrm{mM}$ glutamine and $50 \mu \mathrm{g} / \mathrm{ml}$ gentamycin for $48 \mathrm{~h}$ before PMA stimulation. The supernatants from different cells were collected and processed for LPA analysis.

LPA analysis. LPA extraction and purification were performed with a similar method as described by Tokumura et al. [15]. Briefly, the supernatants from the various cell populations were acidified and extracted by methanol/chloroform (2:1, $\mathrm{v} / \mathrm{v})$. After mixing with chloroform and $\mathrm{H}_{2} \mathrm{O}$, LPA was extracted into the chloroform phase and the extract was concentrated at $40^{\circ} \mathrm{C}$ under nitrogen. The residue was dissolved in methanol/chloroform $(2: 1, \mathrm{v} / \mathrm{v})$ and loaded on a silica gel plate. The developing solvent was chloroform/methanol/ammonium hydroxide $(65: 35: 5.5, \mathrm{v} / \mathrm{v} / \mathrm{v})$. LPA and other phospholipids were detected by spraying the plates with $0.1 \%$ 8-anilino-1naphthalenesulfonic acid in water and visualized under ultraviolet light. LPA spots resolved by TLC were scraped from the silica gel plates and hydrolyzed in $1 \mathrm{M}$ ethanolic $\mathrm{KOH}$. The resulting fatty acids were transmethylated in the presence of behenic acid (Nu Check Prep. Inc., Elysian, $\mathrm{MN}$ ) as an internal standard with $\mathrm{BCl}_{3}-$ methanol reagent (Supelco, Inc., Pittsburgh, PA). After transmethylation, the fatty acid esters were extracted with petroleum ether and quantified by HewlettPackard Model 5890 gas chromatograph equipped with a column $(1.83 \mathrm{~m} \times 2 \mathrm{~mm})$ coated with $3 \%$ SP-2310, 2\% SP-2300, on 100/120 Chromosorb W AW (Supelco, Inc. Bellefonte, PA). Two fatty methyl esters standard mixtures were obtained from Nu Check Prep. Inc. Concentrations of LPA and each individual species were derived from the fatty acid ester content and calibrated with internal standard.

Statistics. Determination of statistically significant differences between experimental groups was performed using the nonparametric Mann-Whitney test [22]. Differences between each group were considered to be significant when $P$ values of $<0.05$ were obtained.

\section{RESULTS}

PMA-stimulated LPA secretion from HEY cells in a doseand time-dependent manner. LPA was not detected in the supernatant from HEY, OCC1, Hela, Jurkat, K562, MCF7, and MB-MDA-231 cultured in serum-free medium, suggesting that tumor cells do not produce LPA when growth factors are depleted. To produce LPA, PLA 2 activity is likely to be involved [23]. The activation of $\mathrm{PLA}_{2}$ can be conveniently and quickly achieved in vitro by PMA stimulation, since it activates $\mathrm{PKC}$, which in turn, activates some isoforms of $\mathrm{PLA}_{2}$ and PLD [19, 23-27].

PMA stimulated significant LPA production which could be detected in the supernatant of ovarian cancer HEY cells. This 


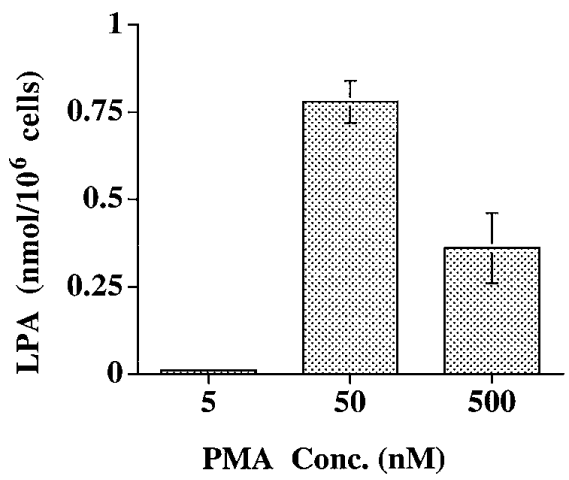

FIG. 1. Dose dependence of PMA-stimulated LPA release into the culture supernatant of HEY cells. HEY cells were cultured as described under Material and Methods. PMA was added to the medium at the indicated concentrations and incubated for $5 \mathrm{~min}$ at $37 \mathrm{C}$. The culture supernatant of HEY cells was collected for LPA analysis. The cell numbers were counted for normalization. LPA analysis was carried as described under Material and Methods. Values are calculated as means \pm S.D. from three experiments.

stimulation was dose and time dependent. As shown in Fig. 1, LPA release was the highest with $50 \mathrm{nM}$ PMA stimulated cells and lower for both 5 and $500 \mathrm{nM}$ PMA. LPA formation and release was rapid (5 min) and very little LPA was detected in the supernatant from HEY cells after $24 \mathrm{~h}$ treatment of $50 \mathrm{nM}$ PMA (Fig. 2).

PMA-stimulated LPA secretion from ovarian cancer and cervical cancer cells, but much lower amounts from breast cancer and leukemia cells. We tested LPA levels in the supernatant from other cells after the treatment of $50 \mathrm{nM}$ PMA for 5 min. As shown in Fig. 3, the two ovarian cancer cell lines HEY and OCC1 produced significant amounts of LPA (0.78 cells and $0.56 \mathrm{nmol} / 10^{6}$ cells). Hela cells, a cervical cancer cell line, also released LPA, although at lower amounts (0.20 $\mathrm{nmol} / 10^{6}$ cells), into the supernatant after PMA treatment. On the contrary, MCF7, an estrogen-response (ER) positive breast cancer cell line and MB-MDA-231, an ER negative breast cancer cell line, only released a very small amount of LPA

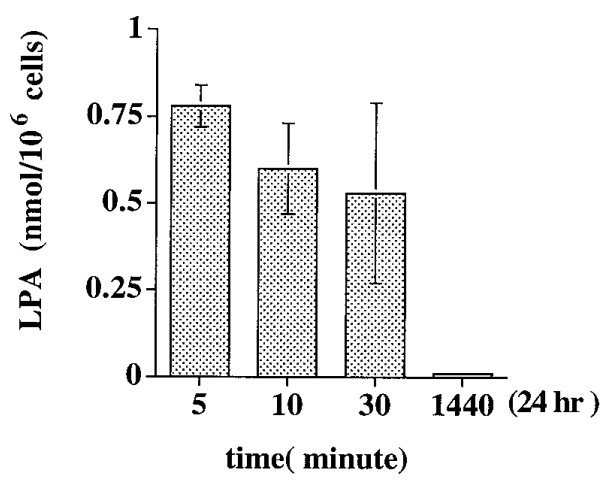

FIG. 2. Time course of PMA $(50 \mathrm{nM})$-stimulated LPA release into the culture supernatant of HEY cells. HEY cells were cultured and stimulated with $50 \mathrm{nM}$ PMA for different times as indicated.

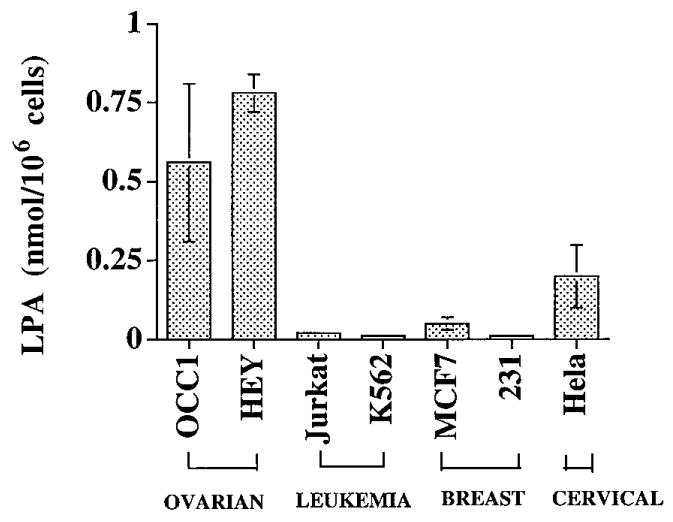

FIG. 3. PMA-stimulated LPA release into the culture supernatant of multiple cell types HEY, OCC1, Hela, Jurkat, K562, MCF7, and MB-MDA231 cells were stimulated with $50 \mathrm{nM}$ PMA for $5 \mathrm{~min}$.

( 0.05 cells and $0.01 \mathrm{nmol} / 10^{6}$ cells, respectively). In addition, two leukemia cell lines (Jurkat and K562) secreted negligible LPA after PMA stimulation.

Statistically, the PMA-stimulated LPA levels in ovarian cancer cells were significantly higher than the PMA-stimulated LPA levels in breast cancer cells $(P=0.002)$ or leukemia cells $(P=0.002)$. The PMA-stimulated LPA levels in cervical cancer cells were also significantly higher than that in breast cancer cells $(P=0.01)$ and leukemia cells $(P=0.02)$.

LPA secretion from ovarian cancer cells by PMA stimulation was $\mathrm{AACOCF}_{3^{-}}$and tamoxifen-sensitive. To investigate the role of phospholipase $A_{2}$ in LPA production in ovarian cancer cells, HEY cells were pretreated with $100 \mu \mathrm{M}$ of $\mathrm{AACOCF}_{3}$, an inhibitor for both $\mathrm{CPLA}_{2}$ and $\mathrm{iPLA}_{2}$, for $12 \mathrm{~min}$ prior to treatment with $50 \mathrm{nM}$ PMA for $5 \mathrm{~min}$. Figure 4 shows that $75.6 \%$ of PMA-stimulated LPA release was inhibited by $\mathrm{AACOCF}_{3}$ pretreatment. Tamoxifen citrate $(50 \mu \mathrm{M}, 20 \mathrm{~min}$ pretreatment) also inhibited PMA-stimulated LPA release (72.2\% inhibition) (data not shown).

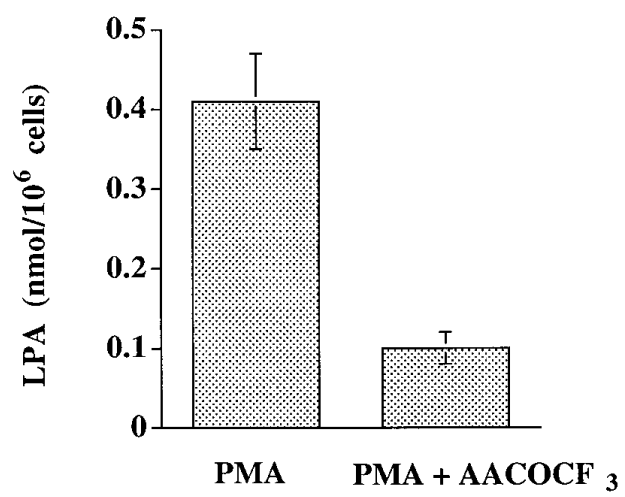

FIG. 4. AACOCF3 inhibited PMA-stimulated LPA release into the supernatant of HEY cells. HEY cells were pretreated with $100 \mu \mathrm{M} \mathrm{AACOCF}{ }_{3}$ for $12 \mathrm{~min}$, prior to the stimulation of $50 \mathrm{nM}$ PMA for $5 \mathrm{~min}$. 


\section{DISCUSSION}

We present data here to show that ovarian and cervical cancer cells can produce LPA under certain conditions. To our knowledge, this is the first demonstration that cancer cells can produce LPA.

Our data show that ovarian cancer cells, but not breast cancer (MCF7 and MB-MDA-231) or leukemia (K562 and Jurkat) cells, secrete LPA. The lack of LPA production in breast and leukemia cells, we believe, is not due to the lack of responsiveness of these cells to PMA. We have previously shown that pretreatment with PMA blocks LPA-induced calcium release in MCF7 and MB-MDA-231 cells (unpublished observation). PMA is known to cause Jurkat cells to proliferate and produce IL-2 [28]. It is well documented that K562 cells differentiate in response to PMA [29, 30]. In addition, PMA has been shown to stimulate aromatase activity in MCF7 cells [31]. PMA also induces a dose-dependent increase in prostaglandin $\mathrm{E}_{2}$ production, inhibits cell growth, and stimulates aromatase activity in 231 cells $[32,33]$. The mechanisms that underlie these differences remain to be investigated. It is possible that under different conditions these breast and leukemia cells may secret LPA into the medium.

Interestingly, the LPA produced by different cancer cells in vitro showed the same tumor type specificity as we observed when measuring LPA in plasma [18]. These results suggest that malignant ovarian epithelial cells may represent an important source of the elevated LPA detected in the plasma of patients with ovarian cancers [18].

We observed that LPA was not secreted by ovarian cancer cells in vitro when growth factors were depleted. Under physiological and/or pathological conditions, however, ovarian cancer cells are under the influence of many growth factors and cytokines, including EGF, transforming growth factor $\beta$, amphiregulin, basic fibroblast growth factor, insulin-like growth factor, interleukin 1, and tumor necrosis factor $\alpha$ [4-6]. Some of these factors have been shown to activate $\mathrm{PLA}_{2}$ in other cell systems in vitro. For example, EGF activates $\mathrm{CPLA}_{2}$ in human squamous carcinoma A431 cells and fibroblasts [34-37]. TGF- $\beta$ regulates the expression of phospholipase $A_{2}(s)$ and induces an increase in cytosolic $85 \mathrm{kDa} \mathrm{PLA}_{2}$ (activity and protein) in macrophages after a prolonged exposure $(>12 \mathrm{~h})$ [38]. IL- 1 and TNF- $\alpha$, but not IL-6, regulate the expression of group II phospholipase $\mathrm{A}_{2}$ in glomerular mesangial cells [39, 40]. Identification of the physiological stimulus for the production of LPA in ovarian cancer cells is under investigation. Studies of LPA production under physiological and pathological conditions, using an animal model, tumor tissue, or primary tumor culture will be necessary to confirm the source of elevated plasma LPA.

Our inhibitor studies strongly suggest the involvement of a cPLA $_{2}$ or an iPLA ${ }_{2}$, but do not rule out the potential involvement of a secretory phospholipase $\mathrm{A}_{2}\left(\mathrm{sPLA}_{2}\right)$ in LPA production. $\mathrm{cPLA}_{2}$ has been shown to be required for activation of
sPLA $_{2}$, and both enzymes are involved in cell activation and signal transduction in $\mathrm{P}_{388} \mathrm{D}_{1}$ macrophage [41]. Recently, a nonpancreatic $\mathrm{SPLA}_{2}$ was reported to be involved in LPA production in platelets [42]. The role of $\mathrm{SPLA}_{2}$ and other enzymes in LPA production and secretion in ovarian cancer cells remains to be determined. If the source and enzymes associated with the elevated LPA levels in patients with ovarian cancer are defined, they may serve as important targets for early intervention of ovarian cancer.

LPA in the medium was diminished after prolonged treatment with PMA, presumably due to the downregulation of PKC and/or rapid conversion of LPA to either phosphatidic acid through reacylation or dephosphorylation to monoacylglycerol through a LPA phosphohydrolase action [23]. In vivo, LPA binds strongly to serum albumin. Albumin not only carries LPA in the serum, but also prolongs its physiological half-life [23]. Therefore, LPA might have a longer half-life in vivo than we have observed in cell culture.

Our previous data on plasma LPA levels [18] do not rule out a potential contribution from platelets to the elevated LPA levels found in gynecological cancer patients [18]. Although we used plasma samples to avoid platelet aggregation during sample collection and analysis, and we did not observe significant difference in platelet counts between patients and normal controls, it is still possible that a platelet abnormality in gynecological patients contributed, in part, to the elevated LPA levels. However, the data we present here indicate that tumor epithelial cells are capable of producing LPA under certain conditions and suggest that they are potential sources for elevated plasma LPA in vivo.

\section{REFERENCES}

1. American Cancer Society: Cancer Facts \& Figures-1998. American Cancer Society Inc., 1998

2. Taylor KJW, Schwartz PE: Screening for early ovarian cancer. Radiology 192:1-10, 1994

3. Schwartz PE, Taylor KJ: Is early detection of ovarian cancer possible? Ann Med 27:519-528, 1995

4. Mills GB, Hashimoto S, Hurteau J, Schmandt R, Campbell S, May C, Hill M, Shaw P, Buckman R, Hogg D: Regulation of Growth of Human Ovarian Cancer Cells. in Sharp F, Mason P, Blackett T, Berek J (eds): Ovarian Cancer 2-Biology Diagnosis and Management. London, Chapman \& Hall, 1992, pp 127-143

5. Mills GB, May C: Regulatory Mechanisms in Ascitic Fluid. in Sharp F, Mason WP, Leake RE (eds): Ovarian Cancer: Biologic and Therapeutic Challenges. London, Chapman \& Hall, 1989, pp 55-62

6. Westermann AM, Beijnen JH, Moolennar WH, Rodenhuis S: Growth factors in human ovarian cancer. Cancer Treat Rev 23:113-131, 1997

7. Berchuch A, Carney M: Human ovarian cancer of the surface epithelium. Biochem Pharmacol 54:541-544, 1997

8. Mills GB, May C, McGill M, Roifman CM, Mellors AA: A putative new growth factor in ascitic fluid from ovarian cancer patients: identification, characterization and mechanism of action. Cancer Res 48:1066-1071, 1988

9. Mills GB, May C, Hill M, Campell S, Shaw P, Marks A: Ascitic fluid from 
human ovarian cancer patients contains growth factors necessary for intraperitoneal growth of human ovarian adenocarcinoma cells. J Clin Invest 86:851-855, 1990

10. Xu Y, Mills GB: Activation of Human Ovarian Cancer Cells: Role of Lipid Factors in Ascitic Fluid. in Sharp F, Mason P, Blackett T, Berek J (eds): Ovarian Cancer 3. London, Chapman \& Hall, 1995, pp 121-135

11. Xu Y, Gaudette DC, Boynton J, Frankel A, Fang XJ, Sharman A, Hurteau J, Casey G, Goodbody A, Mellors A, Holub BJ, Mills GB: Characterization of an ovarian cancer activating factor (OCAF) in ascites from ovarian cancer patients. Clin Cancer Res 1:1223-1232, 1995

12. Xu Y, Fang XJ, Gaudette D, Holub BJ, Casey G, Mills GB: Lysophospholipids activate ovarian and breast cancer cells. Biochem J 309:933940, 1995

13. Eichholitz T, Jalink K, Fahrenfort I, Moolenaar WH: The bioactive phospholipid lysophosphatidic acid is released from activated platelets. Biochem J 291:677-680, 1993

14. Watson SP, McDonnell RT, Lapetina EG: Decanoyl lysophosphatidic acid induces platelet aggregation through an extracellular action, evidence against a second messenger role for lysophosphatidic acid. Biochem J 232:61-66, 1985

15. Tokumura A, Limori M, Niishioka Y, Kitahara M, Sakashita M, Tanaka S: Lysophosphatidic acids induce proliferation of cultured vascular smooth muscle cells from rat aorta. Am J Physiol 267:C204-210, 1994

16. Tigyi G, Henschen A, Miledi R: A factor that activates oscillatory chloride currents in Xenopus oocytes copurifies with a subtraction of serum albumin. J Biol Chem 266:20602-20609, 1991

17. Tigyi G, Miledi R: Lysophosphatidates bound to serum albumin activates membrane currents in Xenopus oocytes and neurite retraction in PC12 pheochromocytoma cells. J Biol Chem 267:21360-21367, 1992

18. Xu Y, Shen Z, Wiper DW, Wu M, Morton RE, Elson P, Kennedy AW, Belinson J, Markman M, Casey G: Lysophosphatidic acid as a potential biomarker for ovarian and other gynecologic cancers. JAMA 719-723, 1998

19. Schumacher KA, Glassen HG, Spath M: Platelet aggregation evoked in vitro and in vivo by phosphatidic acids and lysoderivatives: identity with substances in aged serum (DAS). Thromb Haemostasis 42:631-640, 1979

20. Gerard JM, Robinson P: Identification of the molecular species of lysophosphatidic acid produced when platelets are stimulated by thrombin. Biochim Biophys Acta 1001:282-285, 1989

21. Westermann AM, Havik E, Moolenaar WH, Beijen JH, Rodenhuis S: Lysophosphatidic acid (LPA) levels in peritoneal and pleural malignant effusions. Proc of the AACR 38, No. 922, 1997

22. Zar JH: Biostatistical Analysis, New York, Prentice Hall, 1984, pp 138140

23. Jalink K, Hordijk PL, Moolenaar WH: Growth factor-like effects of lysophosphatidic acid, a novel lipid mediator. Biochim Biophy Acta 1198:185-196, 1994

24. Kennedy CR, Proulx PR, Hebert RL: Role of PLA 2 , PLC, PLD, in bradykenin-induced release of arachidonic acid in MDCK-cells. Am $\mathrm{J}$ Physiol 271:C1064-1072, 1996

25. O'Brian CA, Nancy EW: Biology of the protein kinase C family. Cancer Metastasis Rev 8:199-214, 1985

26. Stanimirovic DB, Bettrand N, McCarron R, Uematsu S, Spatz M: Arachidonic acid release and permeability changes induced by endothelins in human cerebro-microvascular endothelium. Acta Neurochir Suppl 60:7175,1994
27. Gaits F, Fourcade O, LE Balle F, Gueguen G, Gaige B, Gassama-Diagne A, Fauvel J, Salles JP, Mauco G, Simon MF, Chap H: Lysophosphatidic acid as a phospholipid mediator: pathways of synthesis. FEBS Lett 410: 54-58, 1997

28. Xu Y, Casey G, Mills G: Effect of lysophospholipids on signaling in the human Jurkat T cell line. J Cell Physiol 163:441-450, 1995

29. Murray NR, Baumgardner GP, Burns DJ, Fields AP: Protein kinase C isotypes in human erythroleukemia (K562) cell proliferation and differentiation. Evidence that beta II protein kinase $\mathrm{C}$ is required for proliferation. J Biol Chem 268:15847-53, 1993

30. Kang CD, Lee BK, Kim KW, Kim CM, Kim SH, Chung BS: Signaling mechanism of PMA induced differentiation of K562 cells. Biochem Biophys Res Commun 221:95-100, 1996

31. Ryde CM, Nicholls JE, Dowsett M: Steroid and growth factor modulation of aromatase activity in MCF7 and T47D breast carcinoma cell lines. Cancer Res 52:1411-1415, 1992

32. Starzec AB, Spanakis E, Nehme A, Salle V, Veber N, Mainguene C, Planchon P, Valette A, Prevost G, Israel L: Proliferative responses of epithelial cells to 8-bromo-cyclic AMP and to a phorbol ester change during breast pathogenesis. J Cell Physiol 161:31-38, 1994

33. Hughes R, Timmermans P, Schrey MP, Regulation of Hughes R, Timmermans P, Schrey MP: Regulation of arachidonic acid metabolism, aromatase activity and growth in human breast cancer cells by interleukin-1 beta and phorbol ester: dissociation of a mediatory role for prostaglandin $\mathrm{E}_{2}$ in the autocrine control of cell function. Int J Cancer 67:684689, 1996

34. Schalkwijk CG, Spaargaren M, Defize LH, Verkleij AJ, van den Bosch H, Boonstra J: Epidermal growth factor (EGF) induces serine phosphorylation-dependent activation and calcium-dependent translocation of the cytosolic phospholipase $\mathrm{A}_{2}$. Eur J Biochem 231:593-601, 1995

35. Sato T, Nakajima H, Fujio K, Mori Y: Enhancement of prostaglandin E2 production by epidermal growth factor requires the coordinate activation of cytosolic phospholipase $\mathrm{A}_{2}$ and cyclooxygenase 2 in human squamous carcinoma A431 cells. Prostaglandins 53:355-369, 1997

36. Kim BC, Kim JH: Role of Rac GTPase in the nuclear signaling by EGF, FEBS Lett 407:7-12, 1997

37. Kim BC, Lim CJ, Kim JH: Arachidonic acid, a principal product of Rac-activated phospholipase $A_{2}$, stimulates c-fos serum response element via Rho-dependent mechanism. FEBS Lett 415:325-328, 1997

38. Bolognese B, McCord M, Marshall LA: Differential regulation of elicitedperitoneal macrophage $14 \mathrm{kDa}$ and $85 \mathrm{kDa}$ phospholipase $\mathrm{A}_{2}(\mathrm{~s})$ by transforming growth factor-beta. Biochim Biophys Acta 1256:201-209, 1995

39. Muhl H, Geiger T, Pignat W, Marki F, van den Bosch H, Cerletti N, Cox D, McMaster G, Vosbeck K, Pfeilschifter J: Transforming growth factors type-beta and dexamethasone attenuate group II phospholipase $\mathrm{A}_{2}$ gene expression by interleukin-1 and forskolin in rat mesangial cells. FEBS Lett 301:190-194, 1992

40. Pfeilschifter J, Muhl H, Pignat W, Marki F, van den Bosch H: Cytokine regulation of group II phospholipase $\mathrm{A}_{2}$ expression in glomerular mesangial cells. Eur J Clin Pharmacol 44(Suppl 1):S7-9, 1993

41. Balsinde J, Dennis EA: Distinct roles in signal transduction for each of the phospholipase $\mathrm{A}_{2}$ enzymes present in P3881 D1 macrophage. J Biol Chem 271:6758-6765, 1996

42. Fourcade O, Simon MF, Viode C, Rugan N, Lebalie F, Ragab A, Fournie B, Sarda L, Chap H: Secretory phospholipase $\mathrm{A}_{2}$ generates the novel lipid mediator lysophophatidic acid in membrane microvesicles shed form activated cells. Cell 80:919-927, 1995 